\title{
The Role of the Education Quality Assurance Agency (LPMP) in the Education Quality Assurance System (Multi Site Study at 3 Assisted Junior High Schools in Manado City)
}

\author{
Florens S.T. Panungkelan ${ }^{1 a^{*}}$, J.F. Senduk ${ }^{2 b}$, Philoteus E.A. Tuerah ${ }^{2 c}$, and J.A.M. Rawis ${ }^{2 d}$ \\ 1Educational Quality Assurance Institution (LPMP), North Sulawesi, Indonesia; 2State University of Manado, \\ Minahasa, Indonesia \\ a panungkelanflorens@gmail.com; bjfsenduk@unima.ac.id; c philoteustuerah@unima.ac.id, \\ djoulandarawis@unima.ac.id \\ *Corresponding Author : panungkelanflorens@gmail.com
}

\section{Abstract}

This study focuses on the role of the North Sulawesi Education Quality Assurance Agency (LPMP) in the education quality assurance system in 3 junior high schools (SMP) assisted in Manado City. This research includes quality mapping which refers to quality report cards, supervision activities, and facilitation activities carried out at the target schools that are the research locations. The problem of this research is formulated as follows: What is the role of the Education Quality Assurance Agency (LPMP) in mapping the quality of education in 3 assisted junior high schools in Manado City? 3) What is the role of the Education Quality Assurance Agency (LPMP) in facilitating education at 3 target SMP in Manado City?. This study uses a qualitative approach with descriptive analytic methods designed by a multi-site study design. Data collected through observation and documentation. Analysis of the data used includes the flow of activities that occur simultaneously, namely data reduction, data presentation, and drawing conclusions. The results of this study indicate that: 1) The role of North Sulawesi LPMP in quality mapping in the target schools of Manado City is carried out with training and guidance as well as workshops at the target schools. Dissemination of filling in quality report cards and making quality report cards a reference in the preparation of school activity plans and budgets (RKAS). The 3 schools assisted by LPMP in North Sulawesi paid attention by inviting the target schools for each activity; 2) Quality supervision carried out by North Sulawesi LPMP at the target schools can be seen from the stages that are passed such as problem identification, recommendations, implementation assistance, monitoring and evaluation, and quality changes. During the Covid 19 pandemic, the implementation of quality supervision was carried out by utilizing information technology that could minimize the transmission of Covid 19. 3) The role of facilitation and assistance of LPMP in North Sulawesi was carried out by implementing the strategy for implementing the facilitation and mentoring activities of the target schools with three stages: preparation of the target school work program. SPMI, then the implementation and assistance of SPMI target schools, as well as dissemination activities.

Keywords: Quality Assurance; Quality Mapping; Supervision; Facilitation;

\section{Introduction}

Schools as an educational unit that implements all educational programs both from the central and regional levels, has the authority to design an educational plan in improving the quality of education. In relation to improving the quality of education in schools, the government through the Minister of Education and Culture has formed an Education Quality Assurance Agency (LPMP). The Education Quality Assurance Agency has the task of carrying out primary and secondary education.

"The existence of LPMP has tried to help schools in improving the quality of education" (Rosadi, 2012: 18), especially with the existence of target schools / model schools. This school is established and fostered by LPMP to become a reference school for other schools in the vicinity in implementing education quality assurance independently. In addition, the target schools are expected to have a quality culture that develops independently by implementing a systemic, holistic and sustainable education quality assurance cycle. Assisted schools are schools that have not met the National Education Standards (SNP) and are committed and willing to participate in all implementation programs as model schools.

There are several researchers who have researched the education quality assurance system such as Imron Rosadi's Research (2012) on the Effectiveness of the Performance of the Education Quality Assurance 
Agency (LPMP) in improving the quality of education. Research by Riyuzen P. Tuala (2016) on the Management of Quality Improvement of Schools/Madrasahs and Adi Irpan Rojak's (2017) research on the implementation of strategic planning in improving the quality of private madrasah education. Different from previous research, this study focused on the role of LPMP in schools located in Manado City, North Sulawesi

Currently, there are 300 North Sulawesi LPMP target schools spread across all districts and cities. Meanwhile, the rest is the responsibility of local governments. This number is a school that is assisted by LPMP to be able to provide an impact for the surrounding schools. Although LPMP continues to carry out its duties and functions to facilitate the improvement of the quality of primary and secondary education in ensuring the quality of national education.

The problem that often arises from district and city governments is that regional quality report cards have not been used as a reference for preparing plans for improving the quality of education in the regions. This is a problem in itself for LPMP to carry out its role in assisting in improving the quality of education. Therefore, the understanding of the education unit about quality indicators needs to be socialized. Indicators or criteria that can be used as benchmarks for the quality of education, namely: 1) The final outcome of education; 2) Direct educational results, these direct results are used as a starting point for measuring the quality of education of an educational institution, for example written tests, checklists, anecdotes, rating scales, and attitude scales; 3) Educational process; 4) Input instruments, namely tools to interact with raw input (students); 5) Raw input and the environment (Nurhasan, 1994: 390; Zamroni: 2004).

The problems that appear at this time are mapping/ quality report cards that have not been used as a reference for schools to improve quality as outlined in the RKAS (School Budget Activity Plan) and regional quality maps that have not been used as a reference for local governments to improve quality as outlined in the educational activity program plan. area. In addition, the supervision carried out by supervisors and school principals was not optimal. Likewise, the facilitation function of education units is in the context of guaranteeing the quality of education in the target schools. This is where LPMP's role is to facilitate quality assurance to the target schools, even though LPMP is unable to handle all the schools in its area.

North Sulawesi LPMP has partner schools in cities and regencies. Specifically for Manado City, there are 28 target schools consisting of 15 elementary schools, 9 junior high schools, and 4 SMA / SMK levels. According to preliminary data obtained from the North Sulawesi Education Quality Assurance Agency (LPMP), it appears that assistance activities in improving the quality of education in primary and secondary education still need to be addressed because there are still many target schools that follow school quality assurance procedures. From the point of view of the education unit, namely the target schools, it is still necessary to increase the socialization and assistance activities in achieving education quality standards. The quality report card in the education unit has not been used as a reference for quality improvement as outlined in the activity plan and school budget. Not all of them have consistently met the national education standards outlined by the National Education Standards Agency (BSNP). LPMP as an institution that deals with education quality issues is demanded to be able to play a greater role in fostering the target schools.

Therefore, researchers are interested in further researching the role of LPMP in quality mapping, education supervision, and facilitation for improving the quality of education, especially at 3 target SMP in Manado City, namely SMP Negeri 7 Manado, SMP Negeri 2 Manado and SMP Negeri 14 Manado. These three schools were chosen as representatives of the LPMP target schools. This selection is based on school characteristics, educational quality attainments and representation of SMP in the city of Manado.

Based on the research focus, the following research problems can be formulated: 1) What is the role of the Education Quality Assurance Agency (LPMP) in mapping the quality of education at 3 target junior high schools in Manado City ?; 2) What is the role of the Education Quality Assurance Agency (LPMP) in supervising the quality of education at 3 target SMP in Manado City ?; 3) What is the role of the Education Quality Assurance Agency (LPMP) in facilitating the quality of education in 3 target SMP in Manado City? The purpose of this study was to describe and analyze clearly and in detail the role of the Education Quality Assurance Agency (LPMP) in mapping the quality of education, supervising the quality of education and facilitating the quality of education in 3 target junior high schools in Manado City.

\section{Methods}

The approach that will be used in this research is a qualitative approach. Researchers choose a qualitative approach based on the understanding that to research and study the role of the Educational Quality Assurance Agency in the education quality assurance system, requires researchers to be more actively involved in the research process. The study was conducted from September 2020 to Desember 2020. The data sources in this study were elements of leaders and officials in the LPMP and the Principal from three sites of research object. 
Data obtained by observation, interview, and documentation techniques. Data is collected based on facts according to the type of data used. To collect primary data, interview/interview techniques and field observations were used. For secondary data used documentation techniques. The validity of the findings is determined by several examination techniques. The implementation of the inspection technique is based on a number of criteria namely credibility, transferability, reliability, and certainty.

\section{Results and Discussions}

The concept of quality management in educational institutions is an effort to manage all educational resources so that they can produce an educational service that fits or may exceed customer expectations. This is in accordance with the opinion of Juran (1999: 21) "... The purpose of such higher quality is to provide greater customer satisfaction ...". This is in line with Feigenbaum's opinion (Nasution, 2004: 7), which states that quality is full customer satisfaction. As for Deming and Philip B. Crosby, as quoted by Nasution (2004: 7) states that quality is conformity with market needs or quality is whatever the consumer needs and wants. Therefore, the quality must be in accordance with the required or standardized or conformance to requirements.

Likewise Danim's opinion (2003: 53) argues that the quality of input can be viewed from the aspect of the condition of human resources in educational institutions such as school principals, educators, and education personnel, and students. Quality of education can be interpreted as the ability of a product or service unit, which can meet the needs or expectations of customer satisfaction (satisfaction) of education customers. If it is related to the world of education, customers are grouped into two, namely internal customers and external customers, internal customers, namely students or students as learners, and external customers, namely society and the industrial world (Fattah, 2012:2), and Suryobroto (2004) who stated that quality is the level where the design of the specifications of a product and service according to its function and use. In relation to quality management, Bush \& Coleman (2000: 61) describe the hierarchy of quality management by dividing it into Total Quality Management, Quality Assurance, Quality Control, and Inspection.

In Indonesia, there is an education quality assurance institution (LPMP) which has the task of implementing quality assurance, developing models and partnerships for quality assurance of primary and secondary education in provinces based on the policies of the Minister of Education and Culture. LPMP is tasked with implementing quality assurance, model development and quality assurance partnerships for primary and secondary education in the province based on the policy of the Minister of Education and Culture. In this study, focused on the role of LPMP in carrying out the task of quality mapping, quality supervision, and facilitation of the quality of education in schools, namely SMP Negeri 7 Manado, SMP Negeri 2 Manado and SMP Negeri 14 Manado.

In general, the characteristics of these three schools have similarities as target schools with state status, but in terms of performance there are several differences. This is shown in the ability of the management of education quality assurance in each school as well as the educational background and the ability of the principal in the 3 target schools. This difference has an impact on the implementation of the Education Quality Assurance System in schools which includes an Internal Quality Assurance System with a cycle of quality mapping, quality planning, implementation of quality compliance and quality evaluation. The role of LPMP must be maximized so that the achievement of school quality increases from year to year in achieving national standards. With these considerations, this research which examines the extent to which the role of LPMP in the Education Quality Assurance System in target schools is a very interesting problem to research.

The success of achieving the quality of education in 2019 at these 3 target schools is different, SMP Negeri 7 Manado which has been coached for 4 years has a quality achievement of 6.59. SMP Negeri 14 Manado which has been coached for 3 years has a quality achievement of 6.61. Meanwhile, SMP Negeri 2 Manado, which has only been coached for 1 year, has the highest quality achievement compared to the two previous schools, with a quality achievement of 6.99. Based on this data, researchers feel interested and need to examine differences in quality achievement in relation to the role of LPMP North Sulawesi in providing guidance and assistance to target schools.

\subsection{The Role of North Sulawesi LPMP in Mapping the Quality of Education}

The Education Quality Assurance Institute (LPMP) North Sulawesi) has quality assurance programs in target schools.

North Sulawesi LPMP has a big task and responsibility in improving the quality of education. This includes helping education units to achieve national education standards. There are many programs carried out, including a coaching program for North Sulawesi LPMP target schools, the North Sulawesi Provincial 
Education Quality Assurance Agency Partnership program which aims to build cooperation between LPMP North Sulawesi Province and local governments in order to oversee the implementation of the Internal Quality Assurance System (SPMI). in education units, Encourage and assist education units to carry out the SPMI cycle, increase the ability of teachers to manage learning and carry out high-level skill-based assessments (HOTs). In addition, preparing standardized prospective school principals and improving the competence of school principals, improving quality in education units based on the results of mapping and analysis of quality data and recommendations. LPMP also strives to improve the competence of school supervisors in conducting quality supervision in the target schools.

The Head of North Sulawesi LPMP added that the activities at the target schools were carried out through technical guidance and a number of other activities. Technical Guidance (Bimtek) of Internal Quality Assurance Unit (SPMI) especially in the School Education Quality Assurance Team (TPMPS), HOTsBased Assessment Assistance, Selection and Training for Prospective School Principals and Strengthening Principals, Quality Mapping Guidance and Quality Data Analysis, Quality Supervision Guidance . All of these activities are aimed at making the education quality assurance system run well.

LPMP collaborates and partnerships with partner schools and local governments. In quality mapping, LPMP provides technical guidance to the supervisors as regional facilitators so that they can help organize the education quality assurance program. Meanwhile, during the current pandemic, LPMP has adjusted the program with a number of online and offline based innovations.

The LPMP of North Sulawesi Province also established a learning center because it was moved to start efforts to provide available facilities in the form of internet connection. This program is temporarily provided for students living in the vicinity of LPMP in North Sulawesi Province who are constrained or have no internet connection. By continuing to implement strict health protocols to avoid the spread of Covid-19, the LPMP of North Sulawesi Province provides open learning spaces in the form of learning lodges as well as an internet connection.

North Sulawesi LPMP, in carrying out the role of mapping the quality of education in the target schools, holds outreach activities for education units, especially target schools in filling out quality reports. LPMP provides an understanding of the importance of quality report cards in the context of the Internal Quality Assurance System (SPMI) such as analyzing the quality of education, analyzing the root of the problem, planning for quality improvement, implementing quality compliance, and evaluating quality.

The role of LPMP quality mapping during a pandemic is carried out by adjusting indicators and subindicators such as in the format for filling in quality standards

Filling in the quality report cards that education units need to do in normal times before the pandemic with the Covid-19 pandemic is also a challenge for LPMP. There are several adjustments in quality mapping, for example the format for filling out the mapping of education quality based on quality standards according to school conditions and ongoing learning activities. The target schools fill out an assignment worksheet consisting of worksheet 1 which contains maps of changes to SNP indicators and sub-indicators during the Covid-19 emergency and the adaptation period for new habits. Then the task 2 worksheet by Practicing School Self-Evaluation in the Covid-19 Emergency and New Habit Adaptation Periods, as well as the 3 Practices Worksheet Preparing School Work Program Based on EDS (Task 2) in the Covid-19 Emergency Period and the Adaptation Period for New Habits.

North Sulawesi LPMP continues to strive so that quality assurance activities are well controlled and carried out in education units with monitoring and evaluation activities at all target schools. This activity takes place online in order to anticipate the spread of covid-19. However, activities that require direct meetings can be carried out with strict health procedures, for example by conducting rapid tests before activities and maintaining the health of participants in each training activity and so on.

North Sulawesi LPMP always provides socialization related to the mapping of education quality. Communication between LPMP and LPMP target schools is going well. Any information needed can be served properly. In terms of quality mapping, the school fills in the quality report cards according to standards and based on the school self evaluation (EDS) analysis on school quality reports. It is important to be able to implement a school education quality assurance system that shows a sustainable and measurable change in quality.

\subsection{The Role of North Sulawesi LPMP in Supervision of the Quality of Education}

The role of Quality Supervision is also inseparable from the duties and functions of LPMP. Therefore, LPMP in Quality Supervision collaborates with schools to provide guidance especially for supervisors. Supervision is carried out, it is hoped that it can oversee efforts to improve the quality of education units, namely by providing access and assistance to the supervisors of the target schools. In addition, it provides information reinforcement about the duties of a supervisor in accordance with the education quality supervision cycle. 
Supervision has benefits for the target schools in improving and enhancing the quality of education in each education unit.

Quality supervision activities are aimed at fostering school principals and teachers to better understand the true goals of education and the role of schools in realizing these goals. In addition, it helps principals and teachers make a critical diagnosis of their activities and teaching and learning difficulties, and helps them plan future improvements so that the quality of education will increase. LPMP strives so that the quality supervision activities carried out can take place optimally starting from problem identification, recommendations, implementation assistance, monitoring and evaluation, and quality changes.

During the Covid-19 pandemic, supervision activities experienced an adjustment, namely the use of information technology and utilizing applications or platforms that support each activity. Quality supervision is carried out using an Instant message sending application, namely by forming a group of supervisors/target schools, holding Focus Group Discussion (FGD) meetings, by sending invitations to discuss in groups and making meeting resumes. Besides that, school observations were also carried out, by sending picture/video observation documents using video calls, conducting interviews via voice and video text, also working on reviews of improving the document design by sending files and providing comments. Quality supervision is also carried out in virtual classes, namely by inviting supervisors or target schools in virtual classes to hold FGD meetings to conduct school observations and reviews and refine document designs. Quality supervision on the teleconference platform is carried out by inviting the target school supervisors to a seminar FGD meeting and then discussing the material through displaying file and video documents as well as conducting school observations.

The implementation of quality supervision is carried out by utilizing information technology that can minimize the transmission of covid 19, namely by quality supervision with instant message applications, supervision with virtual classes, and supervision by teleconference. Furthermore, in adapting to new norms, it is possible for supervision activities to be carried out directly by implementing appropriate health procedures.

According to the researchers' observations, it seems that there is a need for refresher and provisioning for supervisors to have the ability in the field of information technology and broad insights into national education developments. This is so that supervisors can provide material and solutions to problems of quality of education facing schools.

\subsection{The Role of North Sulawesi LPMP in Facilitating Quality of Education}

Researchers interviewed informants at LPMP North Sulawesi to find out about activities to facilitate the quality of education in schools. The LPMP in charge of education quality facilitation activities explained that facilitation activities are a follow-up to the results of quality mapping and recommendations from education supervision. This facilitation and mentoring activity is a form of LPMP support for each education unit, both school principals, teachers and the School Education Quality Assurance Team (TPMPS) in achieving the set education quality standards. Thus, the working relationship between the role of LPMP in quality mapping, then quality supervision, determines what assistance needs to be done at schools.

The strategy for implementing the facilitation and mentoring activities of the target schools is carried out in three stages, namely the preparation of the SPMI target school work program, then the implementation and assistance of the SPMI target schools, as well as dissemination activities So far the LPMP has provided assistance to the target schools based on the results of the quality mapping analysis outlined in the report card. school quality. In accordance with the quality report filled in by the education unit, North Sulawesi LPMP provides assistance. This is a series of important activities that LPMP must undertake as an institution that is responsible for supporting school quality improvement.

Seeing the global conditions in the midst of the Covid-19 pandemic, researchers asked about quality facilitation activities during the pandemic. "During the Covid 19 pandemic, the assistance and facilitation activities carried out by the North Sulawesi LPMP were by holding workshops to conduct video conferences and virtual classes, consultation meetings via video conferencing and instant messaging, and dissemination through webinars by inviting district and city education offices. Activities like this are carried out so that the transmission of the Covid-19 virus does not continue and until later schools can carry out activities as usual". Regarding educational quality facilitation activities, researchers interviewed the head of the target schools to find out the role played by North Sulawesi LPMP in facilitating the quality of education in the target schools. The results of the interview can be described below.

"SMP Negeri 7 Manado, as a school that has been guided by LPMP North Sulawesi for a long time, feels that the LPMP facilitation activities in our school have been carried out well. Considering that there are so many things that need to be done at our school, the presence of staff from LPMP provides a lot of 
input for us for internal quality assurance activities. The quality facilitation we received from LPMP North Sulawesi was in the form of assistance for the preparation of RKAS, in accordance with the recommendations in school quality mapping. Mentoring activities by LPMP are carried out following the programmed schedule of mentoring activities. The impact of this activity for us is very beneficial because it provides us with an understanding of the implementation of activities to achieve school quality according to the set standards."

LPMP provides a positive contribution to the progress of schools, especially in improving quality. North Sulawesi LPMP guidance has an impact on increasing the achievement of the quality of education in schools. The achievement of the quality standard which is still low from year to year has increased as seen in the quality report card. North Sulawesi LPMP facilitation and assistance in the form of mentoring activities for the preparation of RKAS, in accordance with recommendations in school quality mapping. Mentoring activities by LPMP are carried out following the programmed schedule of mentoring activities. The impact of this activity is very useful because it provides us with an understanding of the implementation of activities to achieve school quality according to the set standards.

\section{Conclusion}

Based on the research results, it can be concluded that:

1. The role of North Sulawesi LPMP in quality mapping in the Manado City target schools is carried out with training and guidance as well as workshops at the target schools. Dissemination of filling in quality report cards and making quality report cards a reference in the preparation of school activity plans and budgets (RKAS). In the 3 target schools of LPMP, North Sulawesi, they paid attention by inviting the target schools for each activity. During the pandemic, LPMP continued to carry out its role by directing the target schools with Task Worksheets that were filled in according to the indicators and sub-indicators in learning during the Covid-19 Pandemic.

2. Quality supervision carried out by LPMP North Sulawesi at the target schools can be seen from the stages that are passed, such as problem identification, recommendations, implementation assistance, monitoring and evaluation, and quality changes. During the Covid-19 pandemic, quality supervision was carried out by utilizing information technology.

3. Facilitation and Assistance Role of LPMP North Sulawesi is implemented by implementing a strategy for the implementation of facilitation and mentoring activities for the target schools. Namely, with three stages: the preparation of a work program for the SPMI target schools, then the implementation and assistance of the SPMI target schools, and dissemination activities.

\section{References}

Allen, IE, Seamen, J. \& Garret, R. (2007). Blending in: The extent and promise of blended education in the United States, USA: The Sloan Consortium.

Bush \& Coleman, (2000). Leadership and Strategic Management in Education. Houston: Gulf Publising.

Danim, Sudarwan. (2008).Visi Baru Manajemen Sekolah: dari Unit Birokasi ke Lembaga Akademik, Jakarta: Bumi Aksara.

Fatah, N. (2012). Sistem Penjaminan Mutu Pendidikan: dalam Konteks Penerpan MBS, Bandung: Remaja Rosdakarya.

Fattah, N. (1996). Landasan Manajemen Pendidikan, Bandung: PT Remaja Rosdakarya.

Juran, J. M., (1993). Quality Planning and Analysis: From Product Development Through Use (Third Edition), United States of America: McGraw-Hill, Inc.

Juran, J. (1986). The Juran Trilogy, Quality Progress, Vol. 19, No. 8.

Juran, Joseph N. \& A. Blanton Godfray (Edit.), (1999). Juran's Quality Handbook New York: McGraw-Hill.

Nasution, M.N. (2004), Manajemen Mutu terpadu, Jakarta: Ghalia Indonesia, Cet. ke-3.

Nurhasan, (1994). Konvensi Nasional Pendidikan Indonesia, Kurikulum untuk Abad 21, Indikator cara pengukuran Faktor-faktor yang mempengaruhi Mutu Pendidikan, PT. Sindo.

Rojak, Adi Irpan. (2017). Implementasi Perencanaan Strategis Dalam Meningkatkan Mutu Pendidikan Madrasah Swasta, Tesis, Program Pascasarjana UIN Maulana Malik Ibrahim Malang.Tidak Dipublikasikan.

Rosadi, K.I., (2012). Efektifitas Kinerja Lembaga Penjaminan Mutu Pendidikan (LPMP) Dalam Meningkatkan Mutu Pendidikan, Jurnal Administrasi Pendidikan. Vol. 14. Nomor 1. DOI: https://doi.org/10.17509/jap.v14i1.6703.

Sagala, S. (2007). Managemen Strategik dalam Meningkatkan Mutu Pendidikan. Bandung: Alfabeta.

Sallis, E. (2012). Total Quality Management In Education, IRCiSoD. 
Sallis, Edward, (2012). Total Quality Management in Education (Manajemen Mutu Pendidikan), Cet. XVI, Jakarta : Erlangga.

Sugiyono, (2006). Metode Penelitian Kuantitatif Kualitatif dan RED, Bandung: Alfabeta.

Suryosubroto, B. (2004). Manajemen Pendidikan di Sekolah, Jakarta: PT. Asdi Mahasatya.

Tuala, Riyuzen, P. (2016). Manajemen Peningkatan Mutu Sekolah/Madrasah, Program Doktor (S3), Program Studi Manajemen Pendidikan Islam, Institut Agama Islam Negeri (IAIN) Raden Intan Lampung, Disertasi, Tidak dipublikasikan.

Zamroni. (2007). Meningkatkan Mutu Sekolah. Jakarta : PSAP MuhammadiyahKhajeh-hosseini, M., A.A. Powell,I.J. Bingham. 2003. The interaction between salinity stress and seedvigor during germination of soybean seed. Seed Science and Technology. 31(3): 715-725. 